François Lauzier

Olivier Lesur

\section{Arginine-vasopressin and corticosteroids in septic shock: engaged but not yet married!}

Received: 10 May 2011

Accepted: 15 May 2011

Published online: 21 July 2011

(C) Copyright jointly held by Springer and ESICM 2011

This editorial refers to the article available at:

doi:10.1007/s00134-011-2312-3.

\section{F. Lauzier}

Division des Soins Critiques, Départements de Médecine et d'Anesthésie, Université Laval, Quebec, QC, Canada

\section{F. Lauzier}

Centre de Recherche FRSQ du Centre hospitalier affilié universitaire de Québec, Axe Traumatologie-Urgence-Soins Intensifs, Quebec, QC, Canada

\section{O. Lesur (『)}

Unité des Soins Intensifs Médicaux, Centre de Recherche Clinique Étienne LeBel et Département de Médecine, CHUS, Université de Sherbrooke, 3001, 12eme Avenue Nord, Sherbrooke, QC J1H 5N4, Canada

e-mail: Olivier.Lesur@USherbrooke.ca

Tel.: +1-819-3461110

Fax: +1-819-5645377

Considerable efforts have been made to spare excessive catecholamine exposure and avoid side effects when treating patients with refractory septic shock. Until recently, physiological replacement of arginine-vasopressin (AVP) and corticosteroid (CS) deficits was considered promising but equivocal to improve end-organ function [1], reduce new-onset tachyarrhythmias [2], shorten duration of shock [3], and improve survival [4]. However, two large multicenter randomized controlled trials failed to demonstrate mortality reduction when using physiological doses of AVP [5] and CS [6] and hampered the initial enthusiasm for their widespread use.

In this issue of Intensive Care Medicine, Torgersen et al. [7] evaluate the effect on mortality of adding CS to
AVP in 159 patients with severe septic shock. Patients included in this single-center retrospective study were relatively ill, as outlined by high baseline sepsis-related organ failure assessment (SOFA) score (median score 15), frequent requirement of continuous renal replacement therapy $(99 / 159,62.3 \%)$, and overall intensive care unit (ICU) mortality $(97 / 159,61.0 \%)$. This sample is not fully representative of the severe sepsis population currently encountered in ICUs [8]. Because treatment assignment was not randomized, the authors used three different statistical analyses to account for baseline characteristics imbalance: multivariate logistic regression, Cox proportional hazard model, and Cox model stratified to matched pairs based on propensity score. Both adjusted analyses and propensity score determination were based on covariables such as age, year of admission, baseline SOFA score, and initial AVP dose, and ignored potentially significant confounders or cointerventions like fluid resuscitation or early effective antimicrobial therapy. Improved survival at 28 days was demonstrated with the Cox proportional hazard model, but not with other statistical analyses, maybe due to lack of power. These results should be cautiously interpreted and must not lead to hasty conclusions regarding the benefits of combining AVP and CS.

Two previous studies using retrospective design and prone to similar biases reported consistent results $[9,10]$. Bauer et al. [9] compared 21 patients receiving AVP and CS with 21 patients infused with AVP without CS. Patients were matched for age, sex, acute physiology score component of the acute physiology and chronic health evaluation (APACHE), number of vasopressors, and primary ICU service [9]. Patients receiving CS were more likely to be alive and weaned off vasopressors at day $7(80.9$ vs. $47.6 \%, p=0.02)$, although the 28 -day and hospital mortality were not statistically different. In another retrospective analysis of 778 patients with septic shock enrolled in a multicenter randomized controlled 
Fig. 1 Effect on 28-day mortality of adding CS or not to AVP in patients with septic shock

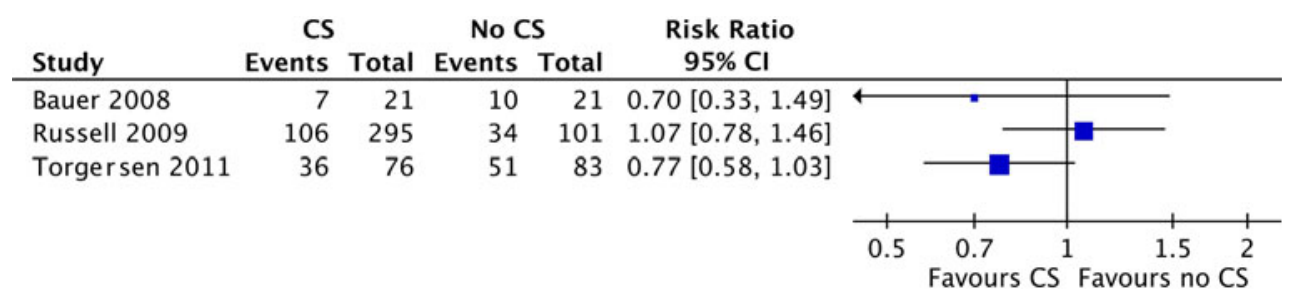

trial [5], Russell et al. [10] reported that patients receiving CS $(n=588)$ had decreased 28-day mortality when treated with AVP and norepinephrine when compared to norepinephrine alone (35.9 vs. $44.7 \%, p=0.03)$. Paradoxically, among patients not receiving CS $(n=190)$, AVP was associated with a trend toward increased mortality compared to norepinephrine (33.7 vs. $21.3 \%$, $p=0.06)$. However, among all patients who received AVP, adding CS had no effect on 28-day mortality (Fig. 1).

The findings of Torgersen, Russell, and Bauer et al. are hypothesis-generating and make physiological sense. Cross talk between CS and AVP may occur at several levels. On the one hand, AVP increases ACTH secretion by corticotropic cells through $\mathrm{V} 1 \mathrm{~b}$ receptors independently of CS negative feedback [11]. This mechanism plays a minimal role under basal conditions, but may become essential during acute stress [12]. On the other hand, CS usually inhibit AVP release centrally [13], whereas enhanced blood content or delayed clearance of AVP has been observed with CS administration in septic shock $[10,14]$, although this finding was recently challenged [15]. In addition, both CS and AVP can modulate or block ATP-sensitive potassium channels, and restore calcium content and constrictive ability of smooth muscle cells $[16,17]$. CS may also retrieve AVP sensitivity of vascular V1a receptors, which are suspected to be downregulated in sepsis [18]. These effects may be mediated by rapid onset of nongenomic mechanisms without protein synthesis involvement, including direct interaction/competition between peptidergic ligands and their respective membrane receptors [19]. In this respect, starting CS before or during AVP infusion did not alter the potential benefit of this combination in the current study [7]. Another putative mechanism is a V1 receptorindependent effect through the resolution of inflammatory processes, including the pleiotropic anti-inflammatory activities of CS and the immunomodulatory properties of AVP on microbial-induced inflammation [20, 21].

In summary, underlying mechanisms of potential interaction between AVP and CS are complex and speculative, although several cross-talk pathways exist. To date, there is insufficient evidence to strongly support a liberal use of either AVP or CS alone or a combination of both in the treatment of septic shock. Therefore, to evaluate the effect on mortality of AVP and CS alone or in combination, an adequately powered $2 \times 2$ factorial double-blind randomized controlled trial with appropriate interaction testing [22] is now warranted.

Acknowledgment F. Lauzier is a Clinical Research Scholar funded by the Fonds de la recherche en santé du Québec.

Conflict of interest None of the authors have any relevant conflict of interest to disclose.

\section{References}

1. Lauzier F, Levy B, Lamarre P, Lesur O (2006) Vasopressin or norepinephrine in early hyperdynamic septic shock: a randomized clinical trial. Intensive Care Med 32:1782-1789

2. Dünser MW, Mayr AJ, Ulmer H, Knotzer H, Sumann G, Pajk W, Friesenecker B, Hasibeder WR (2003) Arginine vasopressin in advanced vasodilatory shock: a prospective, randomized, controlled study. Circulation 107:2313-2319

3. Bollaert PE, Charpentier C, Levy B, Debouverie M, Audibert G, Larcan A (1998) Reversal of late septic shock with supraphysiologic doses of hydrocortisone. Crit Care Med 26:645-650
4. Annane D, Sébille V, Charpentier C, Bollaert P-E, François B, Korach J-M, Capellier G, Cohen Y, Azoulay E, Troché G, Chaumet-Riffaud P, Chaumet-Riffaut P, Bellissant E (2002) Effect of treatment with low doses of hydrocortisone and fludrocortisone on mortality in patients with septic shock. JAMA 288:862-871

5. Russell JA, Walley KR, Singer J, Gordon AC, Hébert PC, Cooper DJ, Holmes CL, Mehta S, Granton JT, Storms MM, Cook DJ, Presneill JJ, Ayers D, VASSTInvestigators (2008) Vasopressin versus norepinephrine infusion in patients with septic shock. N Engl J Med 358:877-887
6. Sprung CL, Annane D, Keh D, Moreno R, Singer M, Freivogel K, Weiss YG, Benbenishty J, Kalenka A, Forst H, Laterre P-F, Reinhart K, Cuthbertson BH, Payen D, Briegel J, CORTICUS Study Group (2008) Hydrocortisone therapy for patients with septic shock. N Engl J Med 358:111-124

7. Torgersen C, Luckner G, Shröder D, Schmittinger C, Rex C, Ulmer H, Dünser M (2011) Concomitant arginine vasopressin and hydrocortisone therapy in severe septic shock: association with mortality. Intensive Care Med. doi: 10.1007/s00134-011-2312-3 
8. Beale R, Reinhart K, Brunkhorst FM, Dobb G, Levy M, Martin G, Martin C, Ramsey G, Silva E, Vallet B, Vincent JL, Janes JM, Sarwat S, Williams MD (2009) Promoting global research excellence in severe sepsis (PROGRESS): lessons from an international sepsis registry. Infection 37:222-232

9. Bauer SR, Lam SW, Cha SS, Oyen LJ (2008) Effect of corticosteroids on arginine vasopressin-containing vasopressor therapy for septic shock: a case control study. J Crit Care 23:500-506

10. Russell JA, Walley KR, Gordon AC, Cooper DJ, Hébert PC, Singer J, Holmes CL, Mehta S, Granton JT, Storms MM, Cook DJ, Presneill JJ (2009) Interaction of vasopressin infusion, corticosteroid treatment, and mortality of septic shock. Crit Care Med 37:811-818

11. Weidenfeld J, Yirmiya R (1996) Effects of bacterial endotoxin on the glucocorticoid feedback regulation of adrenocortical response to stress. Neuroimmunomodulation 3:352-357

12. Lolait SJ, Stewart LQ, Roper JA, Harrison G, Jessop DS, Young WS 3rd, O'Carroll AM (2007) Attenuated stress response to acute lipopolysaccharide challenge and ethanol administration in vasopressin $\mathrm{V} 1 \mathrm{~b}$ receptor knockout mice. J Neuroendocrinol 19:543-551
13. Papanek PE, Sladek CD, Raff H (1997)

Corticosterone inhibition of osmotically stimulated vasopressin from hypothalamic-neurohypophysial explants. Am J Physiol 272:R158-R162

14. Jochberger S, Dunser MW (2011) Influences of hydrocortisone therapy on arginine vasopressin plasma levels in septic shock. Wien Klin Wochenschr 123:245-247

15. de Kruif MD, Lemaire LC, Giebelen IA, Struck J, Morgenthaler NG, Papassotiriou J, Elliott PJ, van der Poll $\mathrm{T}$ (2008) The influence of corticosteroids on the release of novel biomarkers in human endotoxemia. Intensive Care Med 34:518-522

16. Martin SC, Yule DI, Dunne MJ, Gallacher DV, Petersen OH (1989) Vasopressin directly closes ATPsensitive potassium channels evoking membrane depolarization and an increase in the free intracellular $\mathrm{Ca}^{2+}$ concentration in insulin-secreting cells. EMBO J 8:3595-3599

17. d'Emmanuele di Villa Bianca R, Lippolis L, Autore G, Popolo A, Marzocco S, Sorrentino L, Pinto A, Sorrentino R (2003) Dexamethasone improves vascular hyporeactivity induced by LPS in vivo by modulating ATP-sensitive potassium channels activity. Br J Pharmacol 140:91-96
18. Murasawa S, Matsubara H, Kizima K, Maruyama K, Mori Y, Inada M (1995) Glucocorticoids regulate V1a vasopressin receptor expression by increasing mRNA stability in vascular smooth muscle cells. Hypertension 26:665-669

19. Stahn C, Lowenberg M, Hommes DW, Buttgereit F (2007) Molecular mechanisms of glucocorticoid action and selective glucocorticoid receptor agonists. Mol Cell Endocrinol 275:71-78

20. Ullian ME (1999) The role of corticosteroids in the regulation of vascular tone. Cardiovasc Res 41:55-64

21. Gallo-Payet N, Roussy JF, Chagnon F, Roberge C, Lesur O (2008) Hypothalamic-pituitary-adrenal axis multiple and organ dysfunction syndrome in critical illness: a special focus on arginine-vasopressin and apelin. J Organ Dysfunct 4:216-229

22. McAlister FA, Straus SE, Sackett DL, Altman DG (2003) Analysis and reporting of factorial trials: a systematic review. JAMA 289:2545-2553 